INDEPENDENT JOURNAL OF MANAGEMENT \& PRODUCTION (IJM\&P)

http://www.ijmp.jor.br

v. 7, n. 3, July - September 2016

ISSN: 2236-269X

DOI: 10.14807/ijmp.v7i3.433

\title{
SOCIAL QUALITY AND QUALITY OF WORK LIFE OUTLINE THE EMPLOYEES' QUALITY OF LIFE IN INDIAN PUBLIC SECTOR: AN \\ INVESTIGATION
}

\author{
Rinku Sanjeev \\ Institute of Management Studies, Ghaziabad (UP), India \\ E-mail: drrinkusanjeev@gmail.com
}

Urvashi Makkar

G. L. Bajaj Institute of Management \& Research, Greater Noida, India

E-mail: urvashimakkar@gmail.com

Sanjeev Kumar Singh

Apeejay Institute of Technology, School of Management, Greater

Noida, India

E-mail: singhssk@gmail.com

Submission: $30 / 01 / 2016$

Revision: $31 / 08 / 2015$

Accept: 15/09/2015

ABSTRACT

Many researchers have tried to identify the factors that determine quality of life and impact on these factors on social quality. The current research outlines the existing theory and provides an argument which suggests that the trust, loyalty and challenging works also can be part of the construct of social quality. Authors propose a model, supported by data, which suggests ways in which current social theories of trust, loyalty and challenging work may be incorporated within the quality of life framework.

Design/Methodology/Approach The study has two fold objectives.

Firstly, to analyze the factors influencing employees social quality and quality of work life in Indian public sector and secondly, to understand the impact of identified variables on quality of life. The study is based on the primary data, collected from the employees of public sector of India. Data analysis was done using SPSS software. The statistical analysis method employed was descriptive analysis, factor analysis and multiple regressions.

Keywords: Social Quality, Quality of work life, Quality of life, Trust, Loyalty, Challenging work. 


\section{INTRODUCTION}

Social Quality, a revolutionary concept having the potential to influence the lives at professional and personal spheres, has captured the attention of managers and workers similarly. The social quality approach argues that it comes on mainstream of the behavioral sciences and has turned its empirical interest to individual perspectives on 'Quality of Life'.

This approach is trying to conceptualize the quality of life from a scientific perspective. The improvement of quality at the workplace is a concept that has captured the imagination of managers and workers in a similar way. A number of researchers and theorists have tried to identify the kinds of factors that determine quality of life in the work place. It is always proven that a high quality of life is essential for organizations to attract and retain their employees.

Akdere (2006) stated that the issue of work life quality has become vital in the last two decades due to increasing stress of day to day business environment and family structure. Lau, and May (1998) suggested that companies offering better work life quality and supportive work environments would likely gain leverage in hiring and retaining valuable people and companies with high quality of life enjoy excellent growth and profitability.

Mirvis and Lawler (1984), supported the need for objective criterion to measure work life quality. In recent development, governments around the World have been keen to explore inter-connected issues related to improving the health and wellbeing of their citizen and communities. Some of these issues include maintaining and developing social order, human rights, equity and human capabilities (SEN, 1999; 2003).

The social quality approach argues that it comes on mainstream of the behavioral sciences and has turned its empirical interest to individual perspectives on 'Quality of Life'. This approach is trying to conceptualize the quality of life from a scientific perspective.

The authors have verified the contribution of quality of life within the social quality theory. This study outlines the current theory and provides an argument which suggests that the Trust, Loyalty and Challenging works also can be part for the 
construction of social quality. Authors propose a model which suggests ways in which current social theories of trust may be incorporated within the social quality theory.

\section{LITERATURE REVIEW}

Social quality refers to an ideal standard for life which can be acceptable and affordable to the people. It may be defined as the standard of living where people are able to accept, follow and contribute in social, cultural and economic activity for the development and well-being of oneself and their society under the given circumstances (BECK, et al., 2001).

Since social life reflects in representation and identification of self and groups, people must participate as actors and representative of the class they belong. The individuals have their own status but in groups, they represent a collective way to identify and follow the norms. There are four factors which determine environment of social quality. They are Social empowerment, social inclusion, socio-economic security, and social cohesion. It is understood that these factors can be measured in the social symbols and indicators which presents the social index of quality of life (MAESEN; WALKER; KEIGER, 2005; MAESEN; WAKER, 2005).

\subsection{The origins of Social Quality}

The rise of Social Quality started by the initiative launched by a group of social scientist in 1997 under the Dutch Presidency of the European Union. The objective behind this initiative was to develop a conceptual framwork on which a line of strategy can be drawn and activities can be exercised to shape the social life. (BECK, et al., 2001).

The concept of Social Quality drew the attention of social thinkers, philosphers, and researchers upto that extent where the term 'Social Quality' got a special meaning and value in the literature related to society and in other cases. The indicators of quality life were being identified through which the social quality can be measured and quantified.

With this background the rise of social dimensions and empirical research on quality of life, set new goals of societal development and value orientation. At the 
DOI: 10.14807/ijmp.v7i3.433

same time, an awareness and approach developed to structure a social system to address the challenges in meeting 'quality of life'.

\subsection{Quality of Life}

The Quality of Life is a well acknowledged topic of social theory which appreciate and plead for individual well-being, discuss about objective indicators on the one hand (such as income, condition of accommodation, employment etc.) and subjective indicators on the other hand.

This shows concerns how individuals are satisfied about these most important aspects of their lives. These indicators for Quality of Life are meant for adding a new dimension to the concept of well-being, which may be used for measuring social development and growth. The Quality of Life of a country cannot necessarily be understood in terms of GDP or income or consumption, but when looking at the human progress that reflects in eco-cultural environment of societies and bring it on a subjective, as well as an objective indicator and dimension .

The initiative of the European Foundation for the Improvement of Living and Working Conditions reflects that the normal approach to asking for Quality of Life is to identify the key domains of life (housing, employment, health, family relations, social development, etc.) and to identify several indicators under each of these domains (RAPLEY, 2003; FAHEY, et al., 2004).

According to Bohnke (2005), the key indicator for Quality of Life is basically satisfaction about these dimensions. This can be defined as satisfaction with any one of the dimensions or with life in general. It is concerned with the individual's standard of living (living conditions) and his or her perceptions of such circumstances (satisfaction and happiness).

It has been observed that attractive as a policy tool both subjective as well as objective indicators have been well established in social life (NOLL, 2004; NOLL, 2002). It is understood as a means of observing social change and measuring wellbeing in the society (FAHEY, et al., 2004).

Lane (1996) has stated quality of life as a process which includes subjective and objective essentials. He emphasized the active role of personal experience and 
the capacity of individuals - in his terms the 'quality of persons' - as a constitutive element of quality of life:

According to him "Quality of life is well defined by the relation between two subjective elements and a set of objective circumstances. The subjective elements of a high quality of life includes: (1) a sense of well-being and (2) personal development \& learning growth. The objective element is visualized as quality of circumstances which represents prospects for optimum utilization by the individual leading a life".

\subsection{Quality of Life and Social Quality}

The dimensions explored with the Quality of Life approach, rose the issue of reorganizing the concept of Social Quality. The approach for Quality of Life has proved that, after a certain level of monetary growth, overall satisfaction does not enhance the perception of wellbeing and happiness (ECKERSLEY, 2000; ECKERSLEY, 1998; CUMMINS, 1995; CUMMINS, 1998).

However, people are less open about the acceptability for Quality within their society. After a limit of economic threshold, people become conscious about distribution of income, unpaid housework issues, the wastage of natural resources and the unemployment cost (ECKERSLEY, 2000; HALSTEAD, 1998; HAMILTON, 1998).

Individual's own quality of life is most influenced by personal and intimate aspects of life, which protects against several negative changes in personal conditions. This may appear as a loss of confidence for society and its future, which results in terms of loss of individual trust. (ECKERSLEY, 2000). At the same time a big concern is about the negative effects of economic changes on family and social life (PUSEY, 1998). It may result as the collapse of traditional ethics and values in society. It also harms existing family relations and working networks.

The social quality approach underlines both social and the individual aspects. It measures the quality of everyday social life, which is different from the quality of life approach that gets the viewpoint of an individual as independent entity. It is based on 'the social theory'- a sociological approach, which is opposite to the quality of life approach. The social quality approach also actively focuses on the individual, who living in developing social situations. 
The social theory is the result of the dialectical relationship between the collective identities development and human being self-realization. This includes four conditional factors - socioeconomic security, social cohesion, social inclusion and social empowerment. These essential four factors represent the way by which, Individual become competent in the field of social quality. The perquisites of this process are the rule of law, human rights and social justice, social recognition or respect, social responsiveness and the individual's capacity and determination to participate. (VAN DER MAESEN, et al., 2002).

The approach reproduces the human being as social, not only as individual subjects. It also provides a vision for the future of social quality about how the social quality of a society can and should be improved. It provides the fundamental association between need, action and policies. The social quality approach merges together both economic and social development. It also measures the degree of quality of routine life for an acceptable living standard, the structural attribute of societies and their associates, as judged by reference to their impact on society. Basically, it includes both the combination of structural as well as individual-level factors.

The scope of quality of life is vast, extensive, comprising with potentially continuous inventory of realms and indicators and covering the entire world, whereas social quality is initially viewed and defined strongly around its four core components. Furthermore, in difference to quality of life, social quality has an explicitly political or ideological dimension that being associated to a vision of participative social relations. However, the quality of life entails value judgments as neutral.

\subsection{Quality of Work Life}

It has been supported by the researches that quality of work life enhances the feelings of employees towards their jobs, colleagues, and companies which leads to organization's growth and profitability. Quality of work life is one of the most prominent researched area. Researchers have attempted to measure work life quality in a variety of combinations of their questionnaires such as, job satisfaction, organizational commitment, job stress, organizational identification, job involvement etc. Finally work role ambiguity, conflict, and overload were also studied as alternative measures of quality of work life. 
According to Havlovic (1991), Scobel (1975), and Straw and Heckscher (1984), the key parameters observed in quality of work life include job security, better reward systems, higher pay, opportunity for growth, challenging work and participative groups among others. Walton (1974) proposed the conceptual aspects of work life quality where employees perception towards their work organizations could determine their quality of work life. These are adequate and fair compensation, safe and healthy environment, development of human capacities, growth and security, social integrative constitutionalism, the total life space, and social importance.

An extensive Literature review of these disciplines recommended that trust is an important component for the smooth functioning of society and for the progress, development, maintenance and sustainability of the social quality of people's lives (MEYER et al., 2008; MEYER; WARD, 2008; WARD, 2006; WARD; COATES, 2006).

social cohesion, a social quality conditional factor deals with identity, value, and ethics. It is considered by 1) trust in others 2) near by transparency and corruption 3) believe in social rules and institutions 4) humanity and multiculturalism diversity 5) value and belongingness. Ilast few decades it has been observed that general trust and loyalty among people has decreased. Distrust against major institutions has increased, corruptions has improved. This impact working life also.

It is a fact that the importance of trust arises as an important contributor for relationship building and given support to the strength of different relationships for social as well as professional exchange (GRÖNROOS, 2000; HÅKANSSON; SNEHOTA, 1995; MORGAN; HUNT, 1994). Hence, trust is the corner stone in relationship marketing and social exchange theory (MORGAN; HUNT, 1994) It is extensively accepted that it is an important factor to build a strong business relationships (YOUNG; WILKINSON, 1989).

Giddens $(1990 ; 1991 ; 1998)$ highlighted the importance of trust which has been conceptualized as an essential feature of late modernity and a clear cut demarcation between what has been called 'pre-modern' and 'modern' society. Luhmann specified that "one should expect trust to be progressively in demand as a facilitator to handle the complications of the future which technology will cause" (LUHMANN, 1979). 
DOI: 10.14807/ijmp.v7i3.433

This suits within the framework of the 'risk society' (BECK, 1992), hence, the growing perception of risk transports 'trust' in even more significant factor. Therefore, more the risk, more would be the need for trust (LUHMANN, 2005). Consequently, trust assumes role of crucial academic prominence to social scientists who are principally concerned in both understanding the vital factors of social life and also social change.

Beck (1992; 2005) and Giddens, both the researchers, highlighted the significance of trust for an individual and its impact on quality of life. Henceforth, the matter of trust / mistrust is not only about the construction of risks, but that individual and groups working in an organization have established higher levels of reflexivity. Trust is widely accepted as a key managerial concept. Therefore, trust is identified as an essential key for problem resolution (ANDERSON; NARUS, 1984; SCHURR; OZANE, 1985), and play as an important tool of the creativity and challenge involved in solving problems (WOOLTHUIS et al., 2002).

Apart from these, trust is able to convert individual differences into functional conflicts and resulted in productivity benefits (MORGAN; HUNT, 1994). Loyalty has been discussed by many social researchers. Richard Oliver (1999) summits, that loyalty can be visualized as a strong sense of commitment which plays an important role to build impression for individual's professional life and relationship building. Based on the literature review certain questions may occur which can outline the relationship between social quality and quality of life.

Based on the literature review the following hypothesized model of social quality is shown in Figure 1.

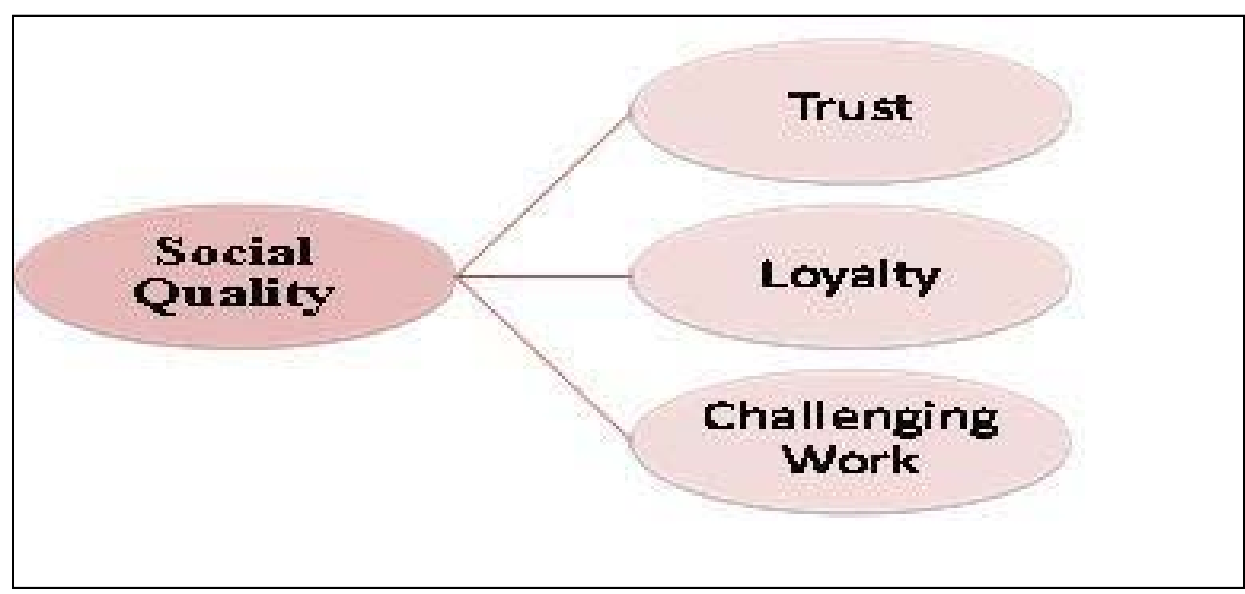

Figure 1: Hypothesized Model of Social Quality 


\section{RESEARCH QUESTIONS AND OBJECTIVES OF THE RESEARCH}

Further this study investigates about the following research questions through the data surveyed.

i. What are the factors which influence employee's social quality and quality of work life?

ii. Is there any impact of trust, loyalty and challenging work on quality of life?

In this regard, the study has two fold objectives:

i. Firstly, to find out the factors influencing employee's social quality and quality of work life in Indian public sector.

ii. Secondly, to understand the impact of identified variables on quality of life.

\section{BACKGROUND OF THE SURVEYS AND DATA ANALYSIS}

The study was exploratory in nature and survey method was used to complete the study. It uses the data for analysis, which was gathered through non-disguised questionnaire during the period April 2015. The primary data was collected using non-probability random sampling technique with a sample size of 184 respondents who are the employees from Public Sector in Delhi and National Capital Region (NCR) in India.

The sample choice is based on the fact as Delhi \& NCR are the representative of whole country and secondly, all working age groups have been included in the sample to rationalize the impact on quality of life. Moreover, public sector in India is presumed as a sector which provides better quality of life with highly attractive wages and incentive policy. These criteria influenced sampling selection by the researchers.

In this survey, the questions to ask were consisting in three parts. The first part intended to capture the demographic profile of the respondent like gender, age, and experience.

The second part contains nine statements to test the level of social quality. It includes following statements: 1. I am provided with the proper training for better performance of my job. 2. I find my work challenging. 3. Work load is properly distributed among all the employees. 4. I trust the seniors with whom I work. 5. I am working in one of the best organizations in the industry. 6.1 am able to balance my 
work and family life.7. I am proud to be a part of this organization. 8. I find my work motivating. 9. At the place where I work, I am treated with respect.

The above mention questions are the indicative of the quality of life led by the employees of the organizations chosen as our sample. Besides this, these questions also indicate the social quality quotient directly or indirectly.

Of course, we need to address that these indicators are neither purely objective indicators nor the subjective indicators. To use the survey data to reflect the condition of social quality, one should be aware of the impact on quality of life.

The third part includes the questions of identified variables related to quality of work life. In this regard, we put questions related to Safety measures, Health facilities, Welfare facilities, Job security, Pay package, Grievance Handling, Lighting facilities and Supervisory support. These questions are able to reveal the impact of quality of work life.

With these questions, we can thus, understand the impact of quality of work life in the public sector.

Data analysis was done using SPSS software. The statistical analysis method employed is Descriptive analysis; factor analysis and multiple regression analysis. The scale used for collecting data was 'Five Point Likert Scale' ranging from 5 for 'strongly agree' down to 1 for 'strongly disagree.

\section{DATA ANALYSIS}

Among the surveyed groups, the basic features of the respondents are below: 47.8 percent respondents were from 25-30 years of age group, 76.1 percent respondents were male staff, 23.9 percent were female staff, and 44.6 percent respondents had worked in the organization for more than 5 yrs (see Table 1).

Table 1: An overview of respondent's demographic profile

\begin{tabular}{|l|c|c|c|}
\hline Gender & Frequency & Percent & Cumulative Percent \\
\hline Male & 140 & 76.1 & 76.1 \\
\hline Female & 44 & 23.9 & 23.9 \\
\hline Age & 35 & 19.0 & 19.0 \\
\hline $20-25$ yrs & 88 & 47.8 & 66.8 \\
\hline $25-30$ yrs & \multicolumn{4}{|l|}{} \\
\hline
\end{tabular}


ISSN: 2236-269X

DOI: 10.14807/ijmp.v7i3.433

\begin{tabular}{|l|c|c|c|}
\hline $30-35$ yrs & 31 & 16.8 & 83.7 \\
\hline $35-40$ yrs & 9 & 4.9 & 88.6 \\
\hline Above 40 yrs & 21 & 11.4 & 100.0 \\
\hline Work Experience & 15 & 8.2 & 8.2 \\
\hline $0-2$ yrs & 26 & 14.1 & 22.3 \\
\hline $2-3 y r s$ & 61 & 33.2 & 55.4 \\
\hline $3-5$ yrs & 82 & 44.6 & 100.0 \\
\hline Above 5 yrs & \multicolumn{4}{|l|}{} \\
\hline
\end{tabular}

\subsection{Factor analysis for Quality of Work life:}

According to the above mentioned methodological notes, we develop further for data analysis. Factor analysis has been used to find out the factors influencing employee's social quality and quality of work life. The Strength of relationship among variables is strong. It presents good idea to proceed for factor analysis of the data. Factor analysis with principal component by varimax rotation, that was performed to find out the factor structure, revealed one factor. Thus, the one factors explained 47.834 percent of the total variance. All factors' factor loadings and variance values can be seen in Table 2 and Table 3.

Table 2: Factor matrix - quality of work life

\begin{tabular}{|l|l|l|l|}
\hline Component & variables & Component Value & Factor Name \\
\hline C1 & Safety measures (SM) & 0.78 \\
\hline C2 & Health facilities (HF) & 0.774 \\
\hline C3 & Welfare facilities (WF) & 0.731 \\
\hline C4 & Job security (JS) & 0.728 & \multirow{2}{*}{ Quality of work life } \\
\hline C5 & Pay package (PP) & 0.65 \\
\hline C6 & Transparency of Grievance Handling & 0.65 \\
\hline C7 & Lighting facilities (LF) & 0.619 \\
\hline C8 & Supervisory support (SS) & 0.571 & \\
\hline
\end{tabular}


DOI: 10.14807/ijmp.v7i3.433

Table 3: Total variance explained - Quality of Work life

\begin{tabular}{|l|l|l|l|l|l|l|}
\hline \multirow{2}{*}{ Component } & \multicolumn{3}{|l|}{ Initial Eigenvalues } & \multicolumn{3}{|l|}{ Extraction Sums of Squared Loadings } \\
\cline { 2 - 7 } & Total & $\%$ of Variance & Cumulative \% & Total & $\%$ of Variance & Cumulative \% \\
\hline C1 & 3.827 & 47.834 & 47.834 & 3.82 & 47.834 & 47.834 \\
C2 & .892 & 11.147 & 58.981 & 7 & & \\
C3 & .786 & 9.820 & 68.801 & & & \\
C4 & .718 & 8.979 & 77.780 & & & \\
C5 & 616 & 7.704 & 85.484 & & & \\
C6 & 436 & 5.451 & 90.935 & & & \\
C7 & 391 & 4.887 & 95.821 & & & \\
C8 & 334 & 4.179 & 100.000 & & & \\
\hline
\end{tabular}

Extraction Method: Principal Component Analysis.

Accordingly we test the reliability of the data. It is acceptable (.876). We also calculate the kaiser-meyer-olkin measure of sampling, result was .856 (>.80) and significance level was $p=.00(<.05)$, Bartlett's Test of Sphericity value was found $91.275(\mathrm{df}=45)$. Hence, it was acceptable. Accordingly, Factor Analysis refers to the procedure used for data reduction and summarization.

Thus, factor analysis is most frequently used to identify small number of factors that may be used to represent the relationship among the set of inter-related variables. In the current research, high correlation exists between Safety Measures (SM), Health Facilities (HF), Welfare Facilities (WF), Job Security (JS), Pay Package (PP), Transparency of Grievance Handling (TGH), Lighting Facilities (LF), and Supervisory Support (SS). Thus, we can combine these variables to form a single factor as the values are greater than 0.5 , namely Quality of work Life. All these deducted factors directly or indirectly are having strong influence on quality of work life.

\subsection{Factor analysis to know the variables of Social Quality:}

Factor analysis was performed to identify the key factors of social quality. Factor analysis with principal component by varimax rotation, that was performed to find out the factor structure, revealed three factors. The three factors explained 63.411 percent of the total variance. Kaiser-Meyer-Olkin Measure of sampling result was $.796(>.75)$ and significance level was $p=.00(<.05)$, Bartlett's Test of Sphericity 
value was found $451.739(\mathrm{df}=36)$. Hence, the result was acceptable. All factors' factor loadings and variance values can be seen in Table 4.

Table 4: Total variance explained- Social Quality

\begin{tabular}{|c|c|c|c|c|c|c|c|c|c|}
\hline \multirow[b]{2}{*}{ Component } & \multicolumn{3}{|c|}{ Initial Eigenvalues } & \multicolumn{3}{|c|}{$\begin{array}{l}\text { Extraction Sums of Squared } \\
\text { Loadings }\end{array}$} & \multicolumn{3}{|c|}{$\begin{array}{l}\text { Rotation Sums of Squared } \\
\text { Loadings }\end{array}$} \\
\hline & Total & $\begin{array}{l}\% \text { of } \\
\text { Variance }\end{array}$ & $\begin{array}{l}\text { Cumulative } \\
\%\end{array}$ & Total & $\begin{array}{l}\% \text { of } \\
\text { Variance }\end{array}$ & $\begin{array}{l}\text { Cumulative } \\
\%\end{array}$ & Total & $\begin{array}{l}\% \text { of } \\
\text { Variance }\end{array}$ & $\begin{array}{l}\text { Cumulative } \\
\%\end{array}$ \\
\hline C1 & 3.567 & 39.636 & 39.636 & 3.567 & 39.636 & 39.636 & 2.261 & 25.122 & 25.122 \\
\hline $\mathrm{C} 2$ & 1.14 & 12.662 & 52.298 & 1.14 & 12.662 & 52.298 & 1.928 & 21.427 & 46.549 \\
\hline C3 & 1 & 11.113 & 63.411 & 1 & 11.113 & 63.411 & 1.518 & 16.861 & 63.411 \\
\hline $\mathrm{C} 4$ & 0.837 & 9.296 & 72.706 & & & & & & \\
\hline C5 & 0.685 & 7.615 & 80.321 & & & & & & \\
\hline C6 & 0.567 & 6.303 & 86.624 & & & & & & \\
\hline C7 & 0.483 & 5.371 & 91.996 & & & & & & \\
\hline C8 & 0.424 & 4.709 & 96.705 & & & & & & \\
\hline C9 & 0.297 & 3.295 & 100 & & & & & & \\
\hline
\end{tabular}

Extraction Method: Principal Component Analysis.

Rotated Component Matrix has been generated using varimax with Kaiser normalization procedure. All nine variables along with the three extracted factors are given below in Table 5 .

Table 5: Rotated component matrix- Social Quality

\begin{tabular}{|c|c|c|c|c|c|}
\hline & & \multicolumn{3}{|c|}{ Component } & Factor Name \\
\hline & & 1 & 2 & 3 & \multirow{6}{*}{ Trust } \\
\hline C1 & Trust on Seniors & 0.736 & & & \\
\hline $\mathrm{C} 2$ & Treated with Respect & 0684 & & & \\
\hline C3 & Work load is Properly Distributed & 0661 & & & \\
\hline C4 & Provided with Proper Training & 0.591 & & & \\
\hline $\mathrm{C} 5$ & Work and Family Life Balance & 0.53 & 0.521 & & \\
\hline C6 & Best Organization in the Industry & & 0.882 & & \multirow{2}{*}{ Loyalty } \\
\hline C7 & Proud to be part of Organization & & 0811 & & \\
\hline $\mathrm{C} 8$ & Work is Challenging & & & 0.889 & \multirow{2}{*}{ Challenging Work } \\
\hline C9 & Work is Motivating & & & 0.686 & \\
\hline
\end{tabular}

Extraction Method: Principal Component Analysis.

Rotation Method: Varimax with Kaiser Normalization.

a. Rotation converged in 5 iterations.

\section{Three factors found are as: 1) Trust, 2) Loyalty 3) Challenging Work}

Three factors have been extracted as a result of factor analysis and they represent social quality in one and another ways. Accordingly, we can further assess 
the studies of social trust in relation to social quality. Hence the selection of these three factors is fully justified. The cumulative impact of these three factors has directly impact on Social Quality refer to Figure 2.

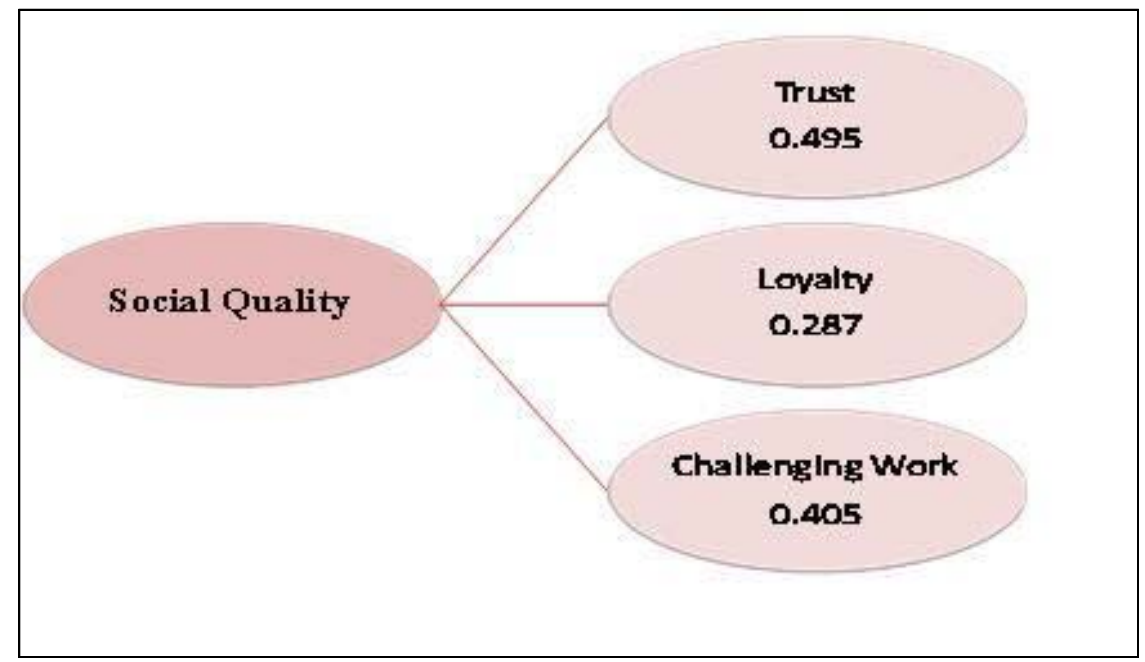

Figure 2: Model of Social Quality (with beta values)

\subsection{Multiple Linear Regression Analysis}

Among these three factors identified in factor analysis, Trust is to be considered more powerful since it projects maximum variance. In order to test the impact of these variables on quality of life, multiple linear regression analysis has been employed. All three variables are considered as independent variable and the social quality is assumed as dependent variable, which are presented in Table 7.

Table 6 reveals the value of adjusted $R$ square is .492 , which indicates that $49 \%$ of variation on quality of work life is explained by three underlying variables of social quality. It can be seen from Table 7 that all three independent variables are positively related with the quality of life.

Table 6: Model summary - Regression analysis

\begin{tabular}{|c|c|c|c|c|c|c|c|c|c|}
\hline & \multirow[b]{2}{*}{$\mathrm{R}$} & \multirow[b]{2}{*}{$\begin{array}{l}\mathrm{R} \\
\text { Square }\end{array}$} & \multirow[b]{2}{*}{$\begin{array}{l}\text { Adjusted } \\
\text { R Square }\end{array}$} & \multirow[b]{2}{*}{$\begin{array}{l}\text { Std. Error } \\
\text { of the } \\
\text { Estimate }\end{array}$} & \multicolumn{5}{|c|}{ Change Statistics } \\
\hline & & & & & $\begin{array}{l}\text { R } \\
\text { Square } \\
\text { Change }\end{array}$ & $\begin{array}{l}\mathrm{F} \\
\text { Change }\end{array}$ & df1 & df2 & $\begin{array}{l}\text { Sig. } F \\
\text { Change }\end{array}$ \\
\hline 1 & $.701^{\mathrm{a}}$ & 0.492 & 0.483 & 0.719 & 0.492 & 58.011 & 3 & 180 & .000 \\
\hline
\end{tabular}

a) Predictors: (Constant), Trust, Loyalty, Challenging work

b) Dependent Variable: Social Quality

- Trust having highest beta coefficient of 0.495 and $t$ value of 9.32 is statistically significant at .01 level. 
- Loyalty is positively correlated with quality of life and statistically found to be significant at .01 level.

- Challenging Work, as another important factor of social quality has significant affect on quality of life and is statistically significant at .01 level.

\section{Hypothesis:}

Ho: There is no impact of trust, loyalty and challenging work on quality of life.

$\boldsymbol{H}_{A}$ : There is impact of trust, loyalty and challenging work on quality of life.

Beta value is significance at .000 so alternative hypothesis is accepted i.e. there is impact of trust, loyalty and challenging work on quality of life.

\section{CONCLUSION:}

Thus, we can conclude that the Beta value is significance at .000 so alternative hypotheses is accepted i.e. there is impact of trust, loyalty and challenging work on social quality. Based on the analysis, the 'Model of Social Quality' (with significance values) is shown in Figure 2.

The current study presents a structured approach which represents a correlation between social quality domains and quality of life. However, trust, loyalty, and challenging work, as the components of social quality have directly correlated impact on quality of life. Trust is the major influencer which impacts the personal and societal levels at work place; it must play a larger role in the current social quality framework before it can form the basis for empirical research.

Overall, the findings of the present study have provided answers to the research questions. The study boost the concept of social quality. Three major factors reflected for overall social quality. These are trust, loyalty and challenging work which outlines the societal environment.

The variables which reflect the quality of work life may be outlined as Safety measures (SM), Welfare facilities (WF), Job security (JS), Pay package (PP), Transparency of Grievance Handling (TGH), Lighting facilities (LF), Supervisory support (SS) and Health facilities (HF). The research represents a significant impact of social quality factors on employee work life quality which means trust on 
DOI: 10.14807/ijmp.v7i3.433

supervisors and colleagues, loyalty with organization, and positive work challenges significantly associate with employee quality of work life.

The finding also provide the insights in efforts to improve the social quality and quality of work life among employees. Trust, loyalty and challenging work have been indicated by respondents as a significant antecedent to improve quality of work life.

Finally, a model of quality of life has been developed in a broad manner which may help the working people in understanding how to lead the life and improve the level in work life (Figure 3).

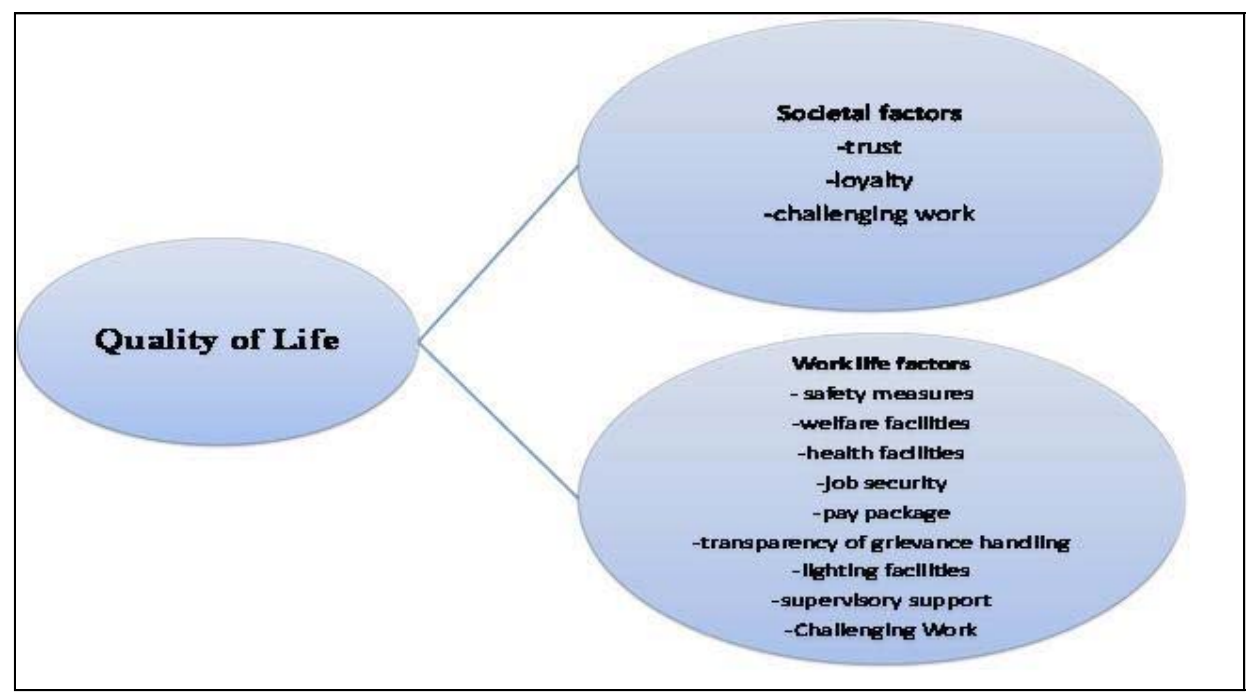

Figure 3: Model of Quality of Life

Based on the result drawn from research a model of quality of life can be proposed as:

1. Quality of life has two major aspects: a) social quality and, b) quality of work life.

2. The factors involved in quality of life are: a) societal factors as trust, loyalty and positive work challenge, and b) work life factors as safety measures, welfare facilities, health facilities, job security, and pay package, transparency of grievance handling, lighting facilities, and supervisory support.

So, overall quality of life can be represented as an integration of several societal and individual indicators which help the person in leading the life.

\section{LIMITATIONS OF THE STUDY AND DIRECTIONS FOR FUTURE RESEARCH}


DOI: 10.14807/ijmp.v7i3.433

Several limitations exist in the present study that may limit the scope of research. First, the sample of this study was derived from employees' of public sector in India. The overall findings of this study are encouraging but the findings of the study cannot be generalized until we include private sector. The variations in the social quality are explained less than fifty percent with the help of trust, loyalty and challenging work. The future research should explore more antecedents of social quality and quality of work life by including private sectors, enabling the comparative analysis also.

\section{REFERENCES}

AKDERE, M. (2006) Improving Quality of Work-Life: Implications for Human Resources. The Business Review, Cambridge, v. 6, n. 1, December, p. 173-177.

ANDERSON, J. C.; NARUS, J. A. (1984) A Model of the Distributor's Perspective of Distributor-Manufacturer Working Relationships, Journal of Marketing, v. 48, n. 4, p. 62-74

BECK, W.; L. J. G.; MAESEN V. D.; THOMESE, F.; WALKER, A. (2001). Social Quality: A Vision for Europe. The Hague: Kluwer Law International.

BECK, W. (1992). Risk Society: Towards a New Modernity. London: Sage Publications.

BECK, W. (2005) World Risk Society. Cambridge: Polity Press.

BOHNKE, P. (2005) First European Quality of Life Survey: Life Satisfaction, happiness and sense of belonging. Dublin, European Foundation for the Improvement of Living and Working Conditions,

CUMMINS, D. A. (1995) On the trail of the goal standard for subjective well-being, Social Indicators Research, v. 35, p. 200.

CUMMINS, D. A. (1998) The second approximation to an international standard for life satisfaction, Social Indicators Research", v. 43, p. 307-334.

ECKERSLEY, R. (2000) The state and the future of nations: implications of subjective measures of personal and social quality of life, Social Indicators Research, v. 52, p. 33-27.

ECKERSLEY, R. (Ed.) (1998) Measuring Progress: is life getting better?, Collingwood Australia, CSINO Publishing.

FAHEY, T.; MAITRE, B.; WHELAN, C. (2004) Quality of Life in Europe, Dublin, European Foundation for the Improvement of Living and Working Conditions.

GIDDENS, A. (1990) The Consequences of Modernity. Stanford: Stanford University Press.

GIDDENS, A. (1991) Modernity and Self-Identity: Self and Society in the Late Modern Age. Stanford: Stanford University Press.

GIDDENS, A. (1998) The Third Way: Renewal of Social Democracy. Cambridge: Polity Press. 
GRONROOS, C. (2000) Service Management and Marketing: A Customer Relationship Management Approach, John Wiley \& Sons, New York, NY.

HAKANSSON, H.; SNEHOTA, I. (1995) Developing Relationships in Business Networks, Routledge, London.

HALSTEAD, J. (1998) The science and politics of new measures of progress. A United States perspective, in Eckersley, R. (Ed.) Measuring Progress. Is life getting better? Collingwood, Australia, CSINO Publishers.

HAMILTON, C. (1998) Measuring changes in economic welfare. the genuine progress indicator for Australia, in Eckersley, R. (Ed.) Measuring progress. Is life getting better? Collingwood Australia, CSINO Publishers.

HAVLOVIC, S. J. (1991) Quality of Work Life and Human Resource Outcomes. Industrial Relations, v. 30, n. 3, Fall. p. 469-479

LANE, ROBERT E. (1996) Quality of Life and Quality of Persons: A New Role for Government. In: A. Offer. Ed. In Pursuit of the Quality of Life. New York: Oxford University Press, p. 256-293

LAU, R. S. M.; MAY, B. E. (1998) A Win-Win Paradigm for Quality of Work Life and Business Performance. Human Resource Development Quarterly, v. 9, n. 3, p. 211-226.

LUHMANN, N. (2005) Risk: a Sociological Theory. New Brunswick, N.J.: Transaction Publishers.

LUHMANN, N. (1979) Trust and Power: Two Works by Niklas Luhmann. Brisbane: John Wiley and Sons.

MAESEN V. D., L. J. G.; WALKER, A.; KEIGER, M. (2005). European Network Indicators of Social Quality: Social Quality: the Final Report. The Hague: European Foundation on Social Quality.

MAESEN V. D., L. J. G.; WALKER, A. (2005). "Indicators of Social Quality: Outcomes of the European Scientific Network," European Journal of Social Quality, v. 3, n. 12, p. 8- 24.

MEYER, S. B.; WARD, P. R. (2008) Do Your Patients Trust You? A Sociological Trust, Social Quality and Wellbeing Understanding of the Implications of Patient Mistrust in Healthcare Professionals. Australasian Medical Journal, v. 1, n. 1, p. 112.

MEYER, S. B.; WARD, P. R.; COVENEY, J.; ROGERS, W. (2008b) Trust in the Health System: an Analysis and Extension of the Social Theories of Giddens and Luhmann. Health Sociology Review, v. 17, n. 2, p. 177-186.

MEYER, S. B.; WARD, P. R.; COVENEY, J.; ROGERS, W. (2008a). Thinking in Synergy Conference, Operationalising Trust in Food, Food Systems and Dietary Recommendations: What can Social Theory Add? Adelaide, SA: Flinders University.

MIRVIS, P.; LAWLER, E. (1984). Accounting for the quality of work life. Journal of Occupational Behaviour, v. 5, p. 197-212.

MORGAN, R. M.; HUNT, S. D. (1994) The commitment-trust theory of relationship marketing, Journal of Marketing, v. 58, n. 3, p. 20-38. 
NOLL, H.-H. (2002) Towards an European system of social indicators: theoretical framework and system architecture, Social Indicators Research, n. 58, p. 547-584.

NOLL, H.-H. (2004), The European System of Social Indicators: a tool for welfare measurement and monitoring social change, Germany 2-4 July, Paper presented to the International Workshop on Researching Well-being in Developing Countries.

OLIVER RICHARD, L. (1999) Whence Consumer Loyalty? Journal of Marketing, Special Issue 1999, p. 33-44

PUSEY, M. (1998) The impact of economic restructuring on women and families: preliminary findings from the middle Australia project, Australian Quarterly, p. 18-27.

RAPLEY, M. (2003) Quality of Life Research. A critical introduction, London, Thousand Oaks, New Delhi, Sage.

SCHURR, P. H.; OZANNE, J. L. (1985) Influences on exchange processes: Buyers' perceptions of a seller's trustworthiness and bargaining toughness, Journal of Consumer Research, n. 11, p. 939-53

SCOBEL, D. N. (1975) Doing away with the Factory Blues. Harvard Business Review, n. 53, Nov-Dec., p. 132-142.

SEN A. (2003) Inequality Reexamined. Oxford: Oxford University Press.

SEN, A. (1999) Development as Freedom. Oxford: Oxford University Press.

STRAW, R. J.; HECKSCHER, C. C. (1984) QWL: new working relationships in the communication industry. Labor Studies Journal. n. 8 winter, p. 261-274.

VAN DER MAESEN, L.; WALKER, M.; KEIZER, M. (2002) Social Quality. The Final Report. European Newwork of Indicators of Social Quality, Amsterdam, European Foundation for Social Quality.

WALTON, R. E. (1974) QWL indicators: prospects and problems. In Portigal, A.H. (Eds.). Measuring the quality of working life. A symposium on Social Indicators of Working Life. Ottawa, March, 19-20.

WARD, P. (2006) Trust, Reflexivity and Dependence: A 'Social Systems Theory' Analysis in/of Medicine. European Journal of Social Quality, v. 6, n. 2, p. 121-133.

WARD, P.; COATES, A. (2006) We Shed Tears, But There is No One There to Wipe Them Up For Us: Narratives of (Mis) trust in a Materially Deprived Community." Health: An Interdisciplinary Journal for the Social Study of Health, Medicine and Trust, Social Quality and Wellbeing Illness, v. 10, n. 3, p. 283-301.

WOOLTHUIS, R. K.; HILLEBRAND, B.; NOOTEBOOM, B. (2002) Trust and formal control in inter organizational relationships, ERIM Report Series Research in Management, Rotterdam, p. 1-18.

YOUNG, L. C.; WILKINSON, I. F. (1989) The Role of Trust and Co-operation in Marketing Channels: A Preliminary Study, European Journal of Marketing, v. 23, n. 2, p.109-122. 